原 著 (Original Contribution)：膜 (MEMBRANE), 11 (3), 177-183 (1986)

\title{
逆浸透膜の熱処理温度と現象論的係数
}

\author{
国眼 孝雄・小林 浩一・清水 賢
}

東京農工大学工学部化学工学科 $\mathbf{\boldsymbol { T }} 184$ 東京都小金井市中町 2-24-16

\section{Heat Treatment Temperature of Membrane and Phenomenological Coefficients for Reverse Osmotic Membrane}

\section{Takao KoKUgan, Hirokazu KobaYASHI and Masaru Shimizu}

Department of Chemical Engineering, Tokyo University of Agriculture and Technology, Koganei, Tokyo 184

In order to study phenomenologically the behavior of permeation through cellulose acetate membrane under reverse osmotic process, experiments were carried out with extensive range of heat treatment temperature and solution concentration. The following results were obtained.

(1) For high temperature treated membrane, reflection coefficient $\sigma$ and solute permeability $p$ are not affected by concentration. But for low temperature treated membrane $\sigma$ has dependence of concentration in $\mathrm{NaCl}$ solution but not in $\mathrm{Na}_{2} \mathrm{SO}_{4}$ solution.

(2) Phenomenological coefficient $-L_{P D}$ is the product of a limit separation degree $\sigma$ and flux coefficient $L_{P}$ and it can be considered as separation efficiency. It has maximum value for heat treatment temperature. Osmotic flow can be estimated directly from the $L_{P D}$ which depends on con entration for $\mathrm{NaCl}$ solution but not for $\mathrm{Na}_{2} \mathrm{SO}_{4}$ solution.

(3) Phenomenological coefficient $L_{D}$ behaves same as solute permeability $p$ for heat treatment temperature but it varies with concentration for lower temperature treated membrane and lower concentration.

Key words: Reverse osmosis, Heat treatment temperature, Phenomenological coefficients, Osmotic flow, Sellulose acetate membrane

\section{1 緒 言}

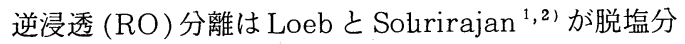
離に用いて以来, 実用可能な分離技術として急速に発展 し, 最近では無機溶媒系, 有機溶媒系などへの種々の分 野でその応用が拡大されつつある ${ }^{3 \sim 7)}$. また高排除率指 向の膜ばかりではなく, ある程度排除率を犠牲にしても 高流束を指向する膜 $\left.{ }^{8}, 9\right)$ など膜の多様化屯進んでいる. てのように一層の拡大が望まれている今日, 基本的な立 場からの分離機構の検討が不可欠となる.一般に, ROの 分離特性は 3 つの沪過係数, すなわち, 純水透過係数 $L_{P}$, 溶質透過係数 $p$, および反射係数 $\sigma$ で表わされるが, これらの係数は熱力学的観点から現象論的係数の関数亡 して定義される. したがって, $\mathrm{RO}$ 分離の機構を基本的
に検討するためには個々の現象論的係数の挙動を正確に 知る必要がある.と乙ろが, 沪過係数については特に高 排除率の膜に対し種々の条件下での検討は数多く報告さ れ，かなり明らかにされてきたが，低排除率，高流束の 膜の膜特性や現象論的係数についての検討は余り見受け られない. 一方, 現象論的係数と種々の操作条件におけ る関係が明らかになれば, 透析法における浸透流などの 影響を直接予測することができる.

そこで本報では, $\mathrm{RO}$ 分離に最むよく用いられる酢酸 セルロース $(\mathrm{CA})$ 膜について, 分離に最も影響を与える 要因の一つである熱処理温度と熱力学的観点から非常に 重要なパラメータである溶質濃度を広範囲に変えた逆浸 透分離実験を行い, 反射係数の低い膜から高い膜の特性 
パラメータに関する濃度依存性について検討しいくつか の知見を得たので報告する．

\section{2 理 論}

一般に, 膜の特性パラメータとして, 純水透過係数 $L_{P}$, 溶質透過係数 $p$, 反射係数 $\sigma$ の 3 つの沪過係数が用 いられ, これらの係数は現象論的係数の関数として定義 される。

非平衡の熱力学に拈ける流れと力との間に成り立つ現 象論的方程式は次式で表わされる.

$$
\begin{aligned}
& J_{V}=L_{P} \Delta P+L_{P D} \Delta \Pi \\
& J_{D}=L_{D P} \cdot \Delta P+L_{D} \Delta \Pi \\
& L_{P D}=L_{D P}
\end{aligned}
$$

式 (3) は Onsager の相反定理と呼ばれる. この線形の現 象論的関係から Kedem-Katchalsky ${ }^{10)}$ は Staverman ${ }^{11}$ によって定義された反射係数 $\sigma$ を用いて次式を導いた。

$$
\begin{aligned}
& J_{V}=L_{P}(\Delta P-\sigma \Delta \Pi) \\
& J_{s}=\omega \Delta \Pi+(1-\sigma) J_{V} C_{s}
\end{aligned}
$$

ここで, 沪過係数 $L_{P}, \omega, \sigma$ と現象論的係数との関係は 次式で表わされる.

$$
\begin{aligned}
& \omega=\bar{C}_{S}\left(L_{P} L_{D}-L_{P D}{ }^{2}\right) / L_{P} \\
& \sigma=-L_{P D} / L_{P}
\end{aligned}
$$

Spiegler-Kedem ${ }^{12)}$ は式(4), (5)を膜の微小区間に適用 し，次のような局所流束式を導いた。

$$
\begin{aligned}
& J_{V}=-P_{1}\left[\frac{d p}{d x}-\sigma \frac{d \Pi}{d x}\right] \\
& J_{s}=-\bar{p} \frac{d C_{s}}{d x}+(1-\sigma) C_{s} J_{V}
\end{aligned}
$$

更に式(8), (9) を膜全体について積分して次式を得た.

$$
\begin{aligned}
& R=\sigma(1-F) /(1-\sigma F) \\
& F=\exp \left[-(1-\sigma) J_{V} / p\right] \\
& p=\omega R_{g} \mathrm{~T}
\end{aligned}
$$

\section{3 実験装置および方法}

使用したCA 膜は Eastman 社製の CA (E 398-3)を Manjikianの標準処法 ${ }^{13,14)}$ で製膜し，未処理から 362 $\mathrm{K}$ までの熱処理温度 $T_{\boldsymbol{t}}$ で 10 分間熱処理した。ただし， 製膜時の蒸発時間は 30 秒, 熱処理後の膜厚は $75 \pm 15 \mu \mathrm{m}$ であった。

実験装置はFig. 1 亿示すように，298Kの恒温槽内に 置かれた連続式平膜型の逆浸透テストセル（有効膜面積 $\left.15.55 \times 10^{-4} \mathrm{~m}^{2}\right)$ を用い, 最大操作圧 $10 \mathrm{MPa}$ で一定時 間圧処理した後, 溶質分離実験を行った。操作圧はブル

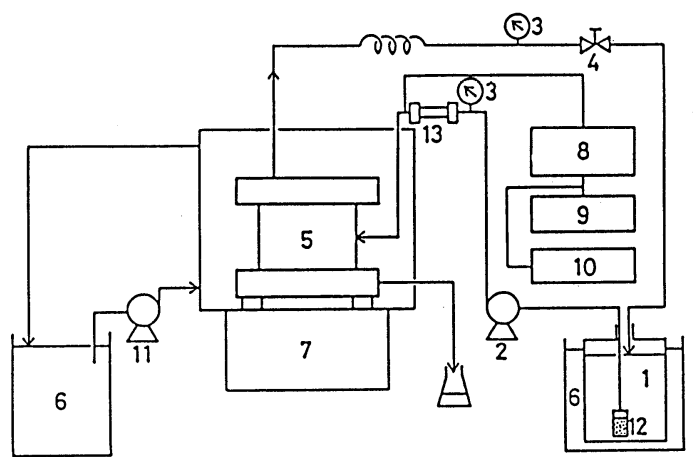

Fig.1 Schematic diagram of experimental apparatus; 1. feed tank 2. double plunger pump 3. pressure gauge 4 . pressure control valve 5 . cell 6 . thermostat(298K) 7. magnetic stirrer 8. pressure tranducer 9. digital voltmeter 10. recorder 11. centrifugal pump 12. solution filter 13. precolumn

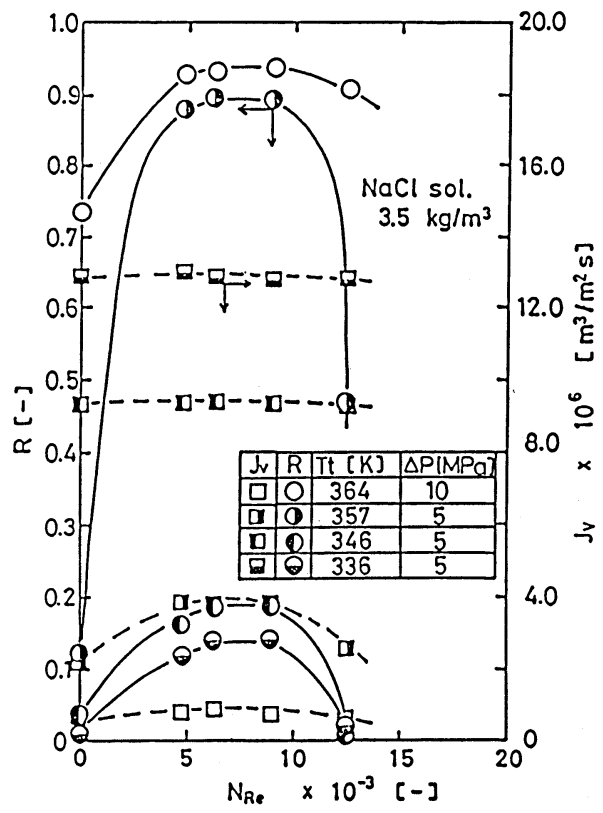

Fig. 2 Effects of agitation Reynolds number Noo on solute rejection $R$ and volume flux $J_{V}$ treated membrane for $\mathrm{NaCl}$ aqueous solution

ドン管式圧力計ならびに圧力変換器を用いて測定し，実 験中, セル内は濃度分極の影響を取り除くためにマグネ ッチィクスターラーで十分に擋拌された．撹拌レイノル ズ $N_{\mathrm{Re}}$ と排除率 $R$ 扰よび流束 $J_{V}$ との関係を Fig. 2 亿示 す. $R$ は $N_{\mathrm{Re}}$ が約 5000 までは急激に増加し, 約 9000 ま 
ではほぼ一定となり，その後急激に減少する。一方， $J_{V}$ は $N_{\mathrm{Re}}$ に関して高温で熱処理されたタイトな膜に対して はほぼ $R$ と同じような関係を示すが，低温で熱処理され たルーズな膜に対してははとんじ影響を受けない，てれ はセル内が $N_{\mathrm{Re}}$ が5000〜9000でほぼ完全に近い状態で 擋拌され，濃度分極が取り除かれた結果と思われる。 $N_{\mathrm{Re}}$ が 9000 以上で急激に減少するのはセル内の回転子 がスターラーの回転に追従できなかったためである，し たがって, 本研究では $N_{\mathrm{Re}}$ を 8000 付近で以下の $\mathrm{RO}$ 分 離実験を行った。 また, 溶液フィルター $(30 \mu)$ とプレカ ラム $(2 \mu)$ で試料中の微粒子の混入を防いだ。試料は塩 化ナトリウム水溶液と特に分離特性のよいあのとして前 報 ${ }^{15)}$ の結果から硫酸ナトリウム水溶液を用いた。溶質 濃度は $3.5 \sim 35.0 \mathrm{~kg} / \mathrm{m}^{2}$ で, 濃度分析は電気伝導度計で

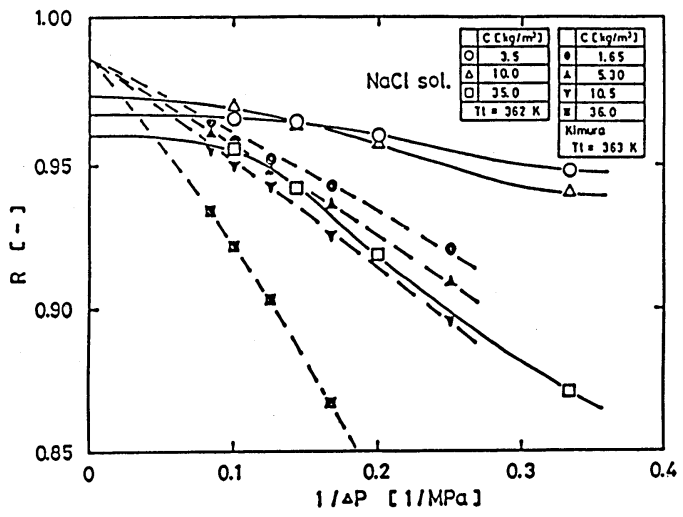

Fig.3-a Effect of operating pressure on solute rejection of high temperature treated membrane for $\mathrm{NaCl}$ aqueous solution

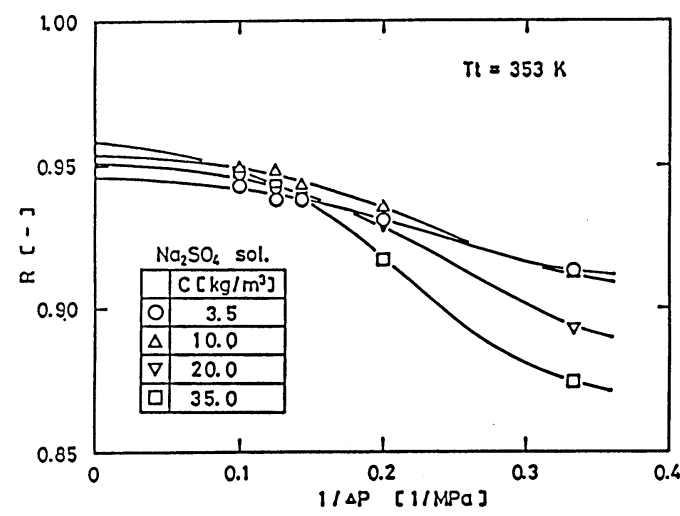

Fig.4-a Effect of operating pressure on solute rejection of high temperature treated membrane for $\mathrm{Na}_{2} \mathrm{SO}_{4}$ aqueous solution
行った。

\section{4 実験結果および考察}

\section{4-1 排除率と操作圧の関係}

Fig. 3, 4 は, 各々, 塩化ナトリウム, 硫酸ナトリウム 水溶液を用いて濃度をパラメータとしたときの高温熱処 理膜および低温熱処理膜における排除率 $R$ 之操作圧 $\Delta P$ との関係を示したあのである．図中で，1/AP をゼロに 外插した点は式(10)，(11)を用いたカーブフィッティング法 によって求められた反射係数 $の$ の值である. 高温熱処理 膜ではどちらの溶質系であ $\sigma$ の濃度依存性は小さく，そ の収束性は比較的よいが, 低温熱処理膜では $\sigma$ は濃度に 大きく依存し, 濃度に対して平行な曲線になっている。 また塩化ナトリウム水溶液に比べて分離しやすい硫酸ナ

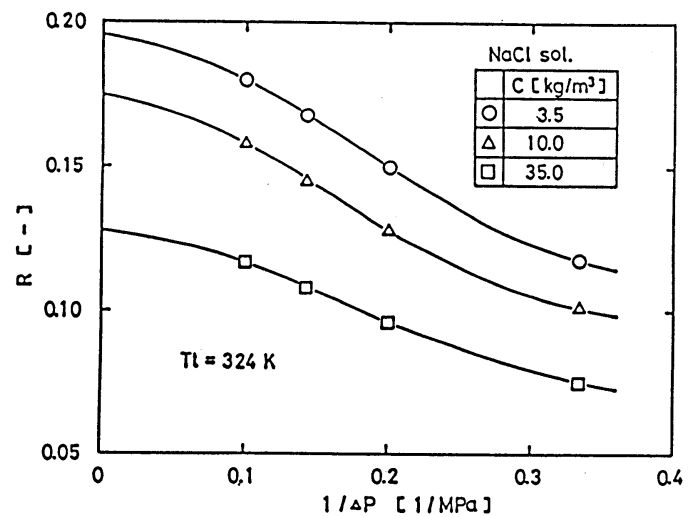

Fig.3-b Effect of operating pressure on solute rejection of low temperature treated membrane for $\mathrm{NaCl}$ aqueous solution

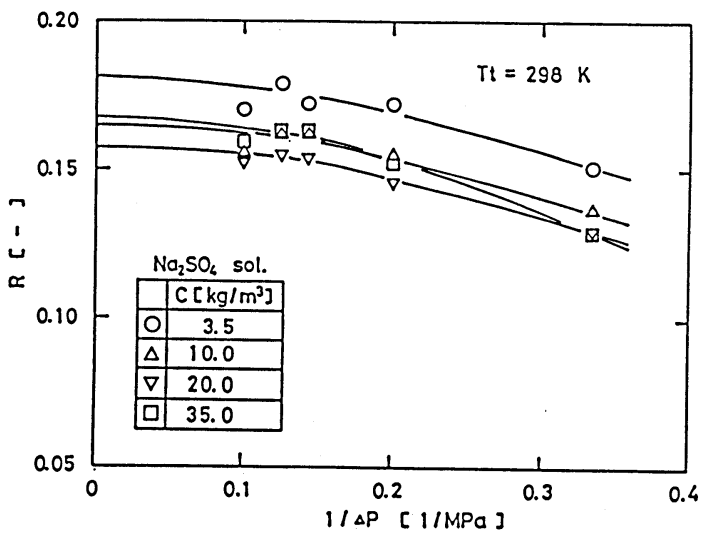

Fig.4-b Effect of operating pressure on solute rejection of low temperature treated membrane for $\mathrm{Na}_{2} \mathrm{SO}_{4}$ aqueous solution 
トリウム水溶液の方が排除率はあまり濃度に依存せず, 未処理の膜についても $\sigma$ 濃度依存性は小さいてとがわ かる．塩化ナトリウム水溶液の高温熱処理膜のグラフ中 で，黒抜きのプロットは木村 ${ }^{16)}$ のデータで $\sigma$ の值は濃 度に依存していないが, 濃度が高くなるに従いまた操作 圧が低いほど排除率が低くなるという傾向は両者ともに 見られる.

Spiegler-Kedem の式 (10), (11) と式(4)から反射係数 $\sigma$ が 1 亿近い高排除性膜の場合には $1 / J_{V}$ の変化に対し $R$ は 溶質透過係数 $P$ に非常に影響を受けやすく, $1 / \Delta P$ に対

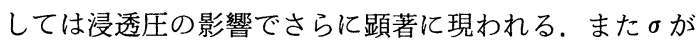
$1 よ り$ かり小さくなるとRは $p$ の変化よりも $\sigma$ の変化 に直接影響され， $R$ が $1 / \Delta P$ あるいは $1 / J_{V}$ に対して平 行に変化する場合には $p$ はほとんよ゙変化しなく $\sigma$ だけの 変化に対応する. したがって, Figs. 3,4 亿扣いて高温 熱処理膜の場合には $\sigma$ は濃度にはほとんど依らずほぼ一 定であるからpが変わらなければならないが, 以上の理 由からRはpが少ししか変化しなくても大きく変り得る ことになる。

\section{4-2 沪過係数と溶質濃度の関係}

Fig. 5 は熱処理温度をパラメータとして溶質透過係数

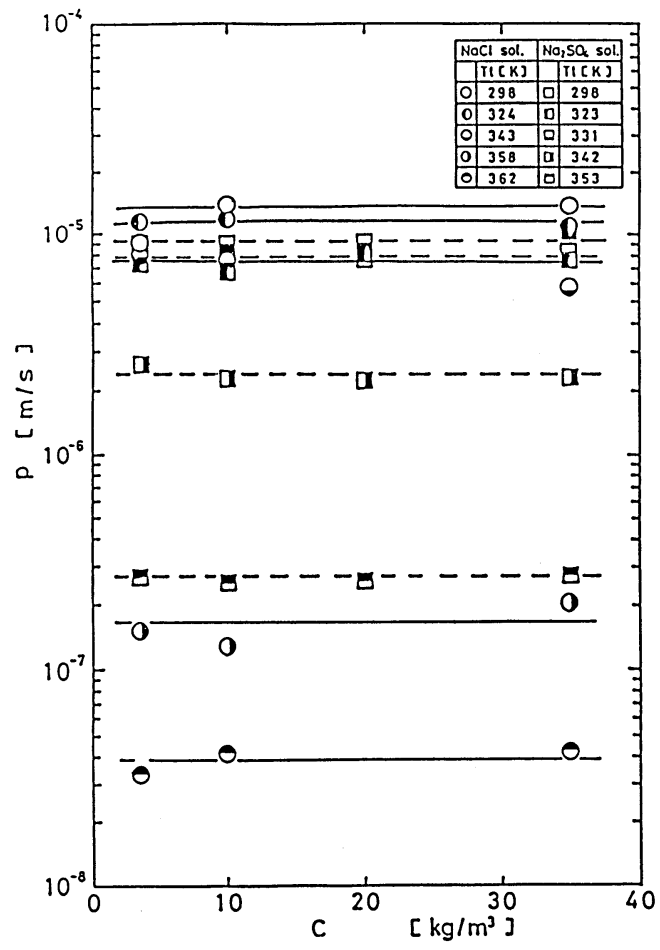

Fig. 5 Relation between solute permeability and solute concentration $p$ 之溶質濃度 $C$ との関係を示したものである，乙の図か ら, 高温熱処理膜での溶質透過係数の濃度依存性はあま り現われていない. 木村ら ${ }^{17,18)}$ は比較的高温熱処理 (352 363K) CA膜に対して溶質透過係数 $p\left(\approx D_{A M}\right.$ / $K \delta ）$ と溶質濃度 C との関係を検討し， $p$ は $C$ にらな いとしている。乙れは $\sigma$ が 1 に近いときにはRはわずか な $p$ の変化に対して, $1 / \Delta P$ に対し顕著に影響を受ける ことと, $\sigma$ のわずかな変化が $R$ の変化を吸収してしまっ た結果と考えることができる. 一方, 熱処理温度が低い 場合 $\left(T_{t}<340 \mathrm{~K}\right)$ には予想されるように Fig. 3-b と Fig. 4-bで濃度に対し平行に変化することからpは $C$ によらないことが予想され, 実験結果もほぼそのように なった. $p$ はいずれの理由であれ高温熱処理膜の場合に 屯, 低温熱処理膜の場合にもいずれの系において溶質濃 度にはほとんどよらないことが明らかになった。

次に反射係数 $\sigma$ と溶質濃度 $C$ との関係を Fig. 6 亿示 す. この図から塩化ナトリウム水溶液については高温熱 処理膜では濃度に関係なくほぼ一定であるが, 低温熱処 理膜では濃度依存性が大きい. $\mathrm{RO}$ 分離性のよい硫酸ナ トリウム水溶液についてはどの熱処理膜に対しても濃度 に関係なくほぼ一定になる結果が得られた。

\section{4-3 現象論的係数と熱処理温度および濃度依存性}

2 成分系の膜透過現象に打ける現象論的係数は式(1) (3)から明らかなように $L_{P}, L_{P D}\left(=L_{D P}\right)$, および $L_{D}$ の

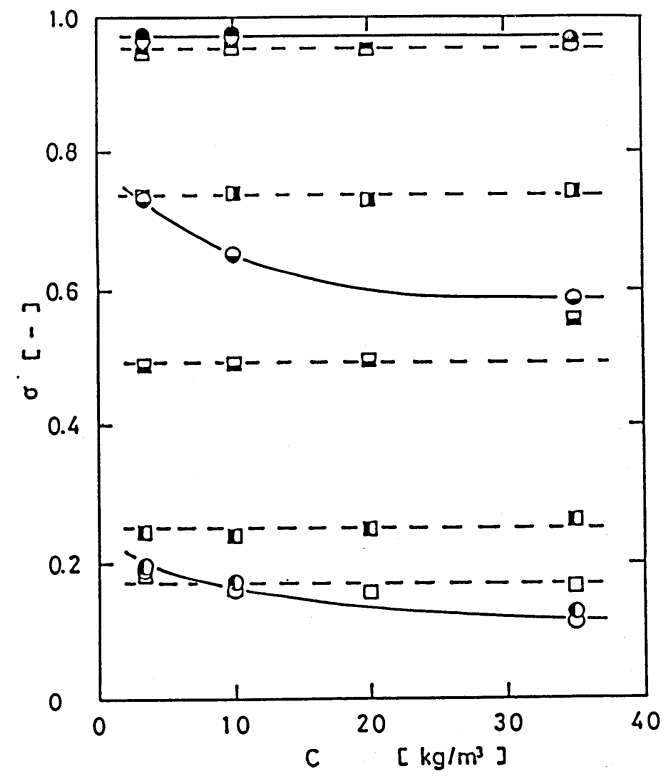

Fig. 6 Relation between reflection coefficient and solute concentration (Keys are the same as those in Fig.5) 
3 種類である. 現象論的係数 $L_{P}$ は洰過係数の中の純水 透過係数と等しいからこてでは $L_{P \mathrm{~d}}$ と $L_{D}$ の 2 種の現象 論的係数について検討する.

\section{4-3-1 現象論的係数 $L_{P D}$}

濃度をパラメー夕にしたときの現象論的係数 $L_{P D}$ と膜 の熱処現温度 Tt との関係を Fig. 7 亿示す. Figs.7-a は 塩化ナトリウム水溶液の場合であり, Fig. 7-b は硫酸ナ トリウム水溶液の場合である. 両者と屯熱処理温度が $333 \sim 343 \mathrm{~K}$ の範囲で最大值をむつ傾向がある. 式(7)か ら一 $L_{P D}$ は $\sigma$ と $L_{P}$ との積で表わされ, $\mathrm{RO}$ 膜の極限で の分離度を表わす $\sigma$ と処理量を表わす $L_{P}$ の積である一 $L_{P D}$ は分離効率を表わす民度と考えることができる. $\mathrm{RO}$ 分離に扔いて $\sigma$ と $L_{p}$ は一般に相反する関係にある から, 一 $L_{P D}$ は最大值をとることが予想され, 実験的に あ明らかにされた。 また $L_{P D}$ は式(1)で操作圧 $\Delta P=0$ の の場合の浸透圧差, すなわち濃度差によって生じる浸透 流の大きさを表わすパラメータであるから, 浸透流に対 しても最大值を呈する熱処理温度が存在するてとが現象 論的係数から直接わかる. 更に, 現象論的係数が最大值 を呈する熱処理温度は沪過係数の変化が顕著に現われ始 める範囲と一致していることは興味あるてとである。一 方, 一 $L_{P D}$ の濃度依存性については塩化ナトリウム水溶 液が濃度の増加に伴って減少するのに対し, 分離特性の よい硫酸ナトリウム水溶液にはその影響は見受けられな い.

一般に現象論的係数は一定ではなく濃度の関数といわ れており, 例えば 2 成分系の拡散現象に扔ける現象論的 係数はモル易動度と濃度の積で表わされる ${ }^{19}$ 。 このよ

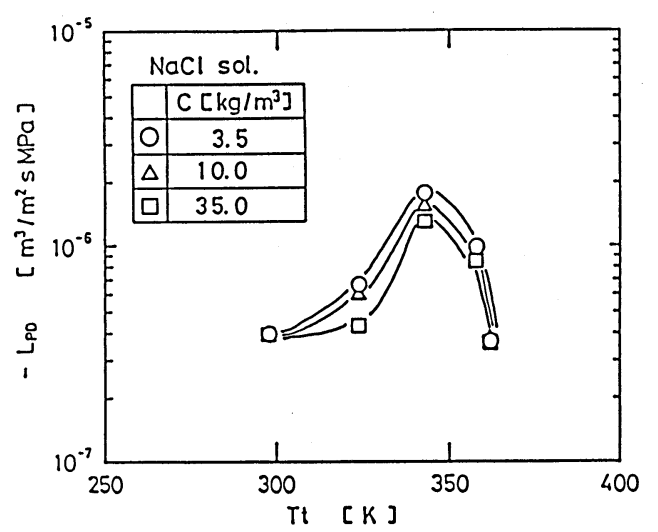

Fig.7-a Relation between phenomenological Coefficient $L_{P D}$ and heat treatment temperature for $\mathrm{NaCl}$ aqueous solution
うは考察から本 $\mathrm{RO}$ 分離に抢ける現象論的係数 $L_{P D}$ の濃度依存性は排除率，すなわち熱処理温度にも影響を 受けることがわかる.

\section{4-3-2 現象論的係数 $L_{D}$}

現象論的係数 $L_{D}$ と熱処理温度 $T_{t}$ との関係を濃度を パラメータにして示したあのが Figs. 8である. Fig.8-a は塩化ナトリウム水溶液の場合であり, Fig. 8-bは硫酸 ナトリウム水溶液の場合である. $L_{D}$ は熱処理温度の増 加に伴って急激に減少する手前（約 $340 \mathrm{~K}$ ）で最大值を あつ傾向にあるが（特に硫酸ナトリウム系で著しい）, 約 $340 \mathrm{~K}$ までは $L_{D}$ の熱処理による影響は少ない. また $L_{D}$ は式(2)で操作圧 $\Delta P=0$ の場合の浸透圧差, すなわち濃 度差によって生じる拡散流の大きさを表わすパラメー夕 であるから沪過係数の $p$ や $L_{P}$ と同様な挙動を呈するあ のと考えられる. しかし， $L_{D}$ の濃度依存性については 溶質濃度が高くなると一般に減少する傾向がある. 現象 論的係数 $L_{D}$ と溶質濃度 $C$ との関係を図示したものが Fig. 9 である. 図から両方の水溶液に対し, その傾向が 明らかであるが溶質濃度が高くなるほど, また熱処理温 度が高くなるほどその変化は少なくなる。

\section{5 結 語}

CA 膜を用いた逆浸透法における透過の挙動を現象論 的に検討するために熱処理温度や溶質濃度を広範囲に変 えた分離実験を行い次のような結果を得た。

(1) 反射係数 $\sigma$ や溶質透過係数 $p$ は高温熱処理膜に対し ては溶質濃度にほとんど依存しないが, 低温熱処理膜の ように排除率の低い膜の場合には $\sigma$ の濃度依存性は系に

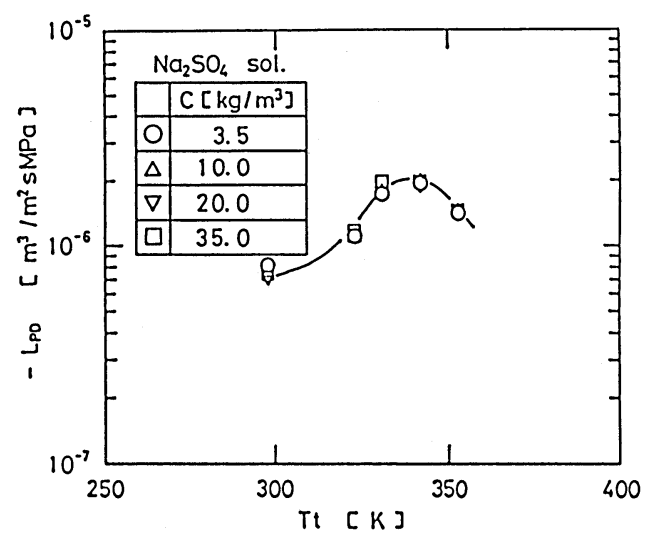

Fig.7-b Relation between phenomenological coefficient $L_{P D}$ and heat treatment temperature for $\mathrm{Na}_{2} \mathrm{SO}_{4}$ aqueous solution 
182 国眼 -小林・清水 : 逆浸透膜の熱処理温度と現象論的係数

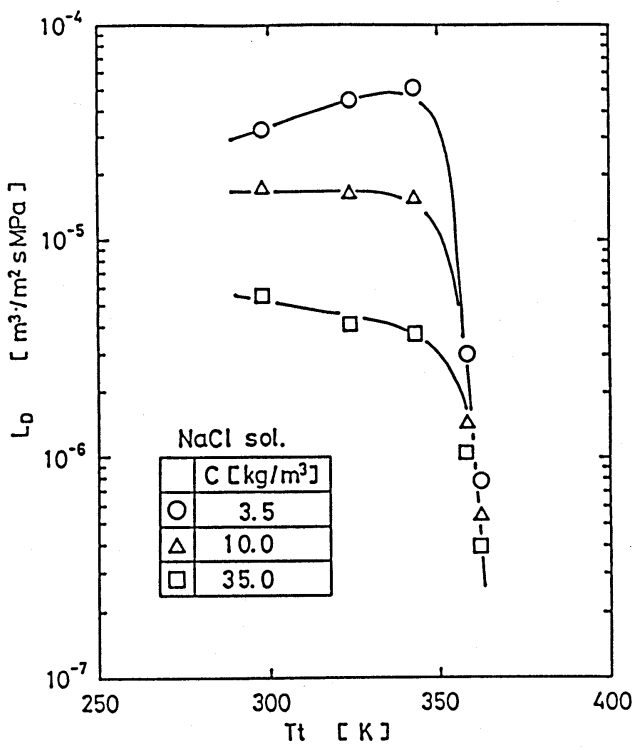

Fig.8-a Relation between phenomenological coefficient $L_{D}$ and heat treatment temperature for $\mathrm{NaCl}$ aqueous solution

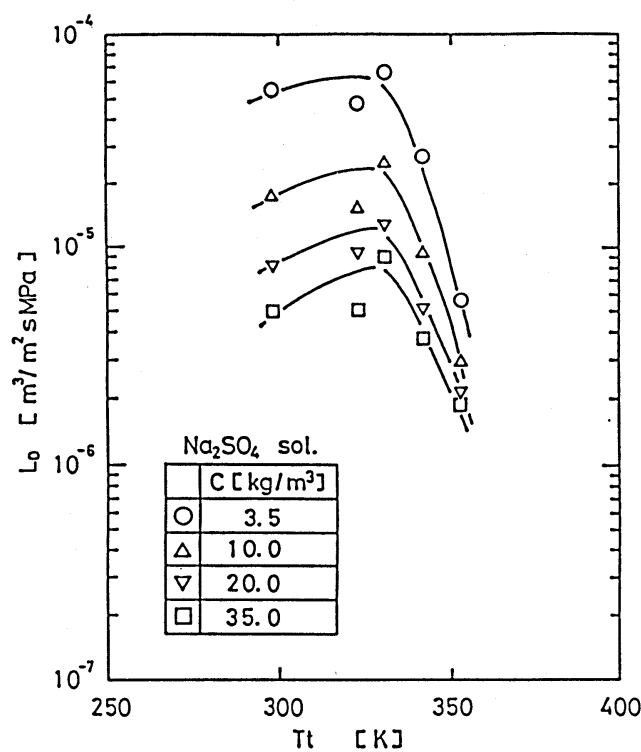

Fig.8-b Relation between phenomenological coefficient $L_{D}$ and heat treatment temperature for $\mathrm{Na}_{2} \mathrm{SO}_{4}$ aqueous solution

よって異なり塩化ナトリウム水溶液では濃度の增加に伴 って減少し，硫酸ナトリウム水溶液の場合にはほとんど 変化しない，一方， $p$ は高温熱処理膜の場合と同様に両 者とも変化しない。

(2) 現象論的係数 $L_{P D}\left(=L_{D P}\right)$ は分離度と処理量との

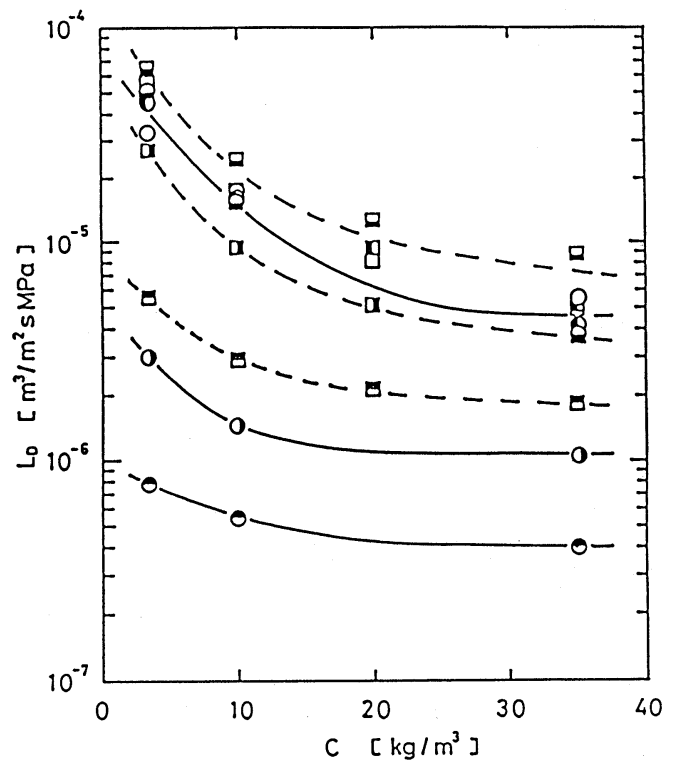

Fig. 9 Relation between phenomenological coefficient $L_{D}$ and solute concentration

(Keys are the same as those in Fig.5)

積で分離効率を表わすパラメータと考えることができ， 最大値を呈する熱処理温度が存在する． $L_{P D}$ の濃度依存 性については塩化ナトリウム水溶液の場合には濃度の増 加に伴って減少するが, 分離性のよい硫酸ナトリウム水 溶液の場合には変化せずほぼ一定である．また浸透流は $L_{P D}$ を用いて直接求めることができる.

(3) 現象論的係数 $L_{D}$ は熱処理温度に対して溶質透過係 数 $p$ と同じような挙動をするが, 濃度については熱処理 温度が低い膜ほど，また濃度が低いほど大きくなる。

\section{Nomenclature}

$C=$ solute concentration

$C_{s}=$ solute concentration

$\left[\mathrm{Kg} / \mathrm{m}^{3}\right]$ in membrane

$\left[\mathrm{mol} / \mathrm{m}^{3}\right]$

$\bar{C}_{s} \quad=$ average solute concentration on both sides of a membrane $\left[\mathrm{mol} / \mathrm{m}^{3}\right]$

$D_{A M}=$ diffusion coefficient in membrane $\left.\left[\mathrm{m}^{2} / \mathrm{s}\right]\right]$

$d \quad=$ length of stirring bar $\quad[\mathrm{m}]$

$F \quad=$ value defined by Eq. (11)

$J_{D} \quad=$ permeation flux of solute relative to solvent $\left[\mathrm{mol} /\left(\mathrm{m}^{2} \cdot \mathrm{s}\right)\right]$

$J_{s}=$ permeation flux of solute $\left[\mathrm{mol} /\left(\mathrm{m}^{2} \cdot \mathrm{s}\right)\right]$ 
$J_{V} \quad=$ permeation volume flux of solution $\quad\left[\mathrm{m}^{3} /\left(\mathrm{m}^{2} \cdot \mathrm{s}\right)\right]$

$K \quad=$ distribution coefficient

$[-]$

$L_{D}, L_{D P}, L_{P}, L_{P D}=$ phenomenological where $L_{P}=$ hydrauric permeability $\left[\mathrm{m}^{3} /\left(\mathrm{m}^{2} \cdot \mathrm{s} \cdot \mathrm{MPa}\right)\right]$

$N_{\mathrm{Re}}=$ agitation Reynolde number $\left(=d^{2} \cdot n \cdot \rho / \mu\right)$

$n \quad=$ agitation speed

$P_{I} \quad=$ intrinsic membrane $\left(=L_{P} \cdot \delta\right)$ permeability $\left[\mathrm{m}^{3} /(\mathrm{m} \cdot \mathrm{s} \cdot \mathrm{MPa})\right]$

$p \quad=$ solute permeability defined by Eq.(12)

$\bar{p} \quad=$ specific hydraulic permeability $\quad(=p \cdot \delta)$ $\left[\mathrm{m}^{2} / \mathrm{s}\right]$

$\Delta P \quad=$ operating pressure $[\mathrm{MPa}]$

$R \quad=$ solute rejection

$R g \quad=$ gas constant $[\mathrm{J} /(\mathrm{mol} \cdot \mathrm{K})]$

$T=$ temperature

Tt = heat treatment temperature

$\Delta \Pi=$ difference of osmotic pressure $[\mathrm{MPa}]$

$\delta=$ thickness of a dense layer

$\mu \quad=$ viscosity

$\rho \quad=$ density

$\left[\mathrm{Kg} / \mathrm{m}^{3}\right]$

$\sigma \quad=$ reflection coefficient

$[-]$

$\omega=$ solute permeability $\left[\mathrm{mol} /\left(\mathrm{m}^{2} \cdot \mathrm{s} \cdot \mathrm{MPa}\right)\right]$

\section{Literature cited}

1) S. Loeb, S. Sourirajan: Advan. Chem. Ser., 38, 117 (1963)

2) idem: U.S.Pat., 3, 133, 132, patented May 12 (1964)

3) A. Iwama: Maku, 7, 341 (1982)

4) K. Yamamoto, H. Ohya: "Maku Riyougijyutsu", Kagaku Kogaku Kyoukai(ed.), Gakkaisyuppan center. p.170 (1982)

5) H. Ohya, J. Taga, Y. Negishi: Ronbunshu, 9, 283 (1983)

6) M. Okazaki, S. Kimura: J. Chem. Eng.Japan, 17, 192 (1984)

7) H. Yanagishita, T. Nakane, H. Yoshitome: Maku, 10, 365 (1985)

8) H. Ohya.: Maku, 10, 101 (1985)

9) M. Tamura: Kagaku Kogaku, 49, 977 (1985)

10) O. Kedem, A. Katchalsky: Biochim. Biophysic. Acta, 27, 229 (1958)

11) A.J. Staverman: Rec. tran. Chim., 70. 344 (1951)

12) K.S. Spiegler, O. Kedem: Desalination, 1, 311 (1966)

13) S. Manjikian: Ind. Eng. Chem., Proc. Res. Develop., 6, 23 (1967)

14) S. Manjikian, S. Loeb, J. W. McCutchan : Proc. First Intern. Symp. on Water Desalination, Washington, D.C., 2, 159 (1965)

15) T. Kokugan, Y. Hirai, H. Kobayashi, M. Shimizu: J. Chem. Eng. Japan., 17,660(1984)

16) S. Kimura: 4 th International Symposium on Fresh Water from the Sea, 4, 197 (1973)

17) S. Kimura, S. Sourirajan: AIChE J., 13, 497 (1967)

18) S. Sourirajan, S. Kimura: Ind. Eng. Chem., Process Design \& Develop., 6, 504 (1967)

19) A. Katchalsky, P.F.Curran: “ Nonequilibrium Thermodynamics in Biophysics", Harvard Univ. Press, 71 (1965) 